\title{
PENGARUH TEACHERS' CRAFT DAN KEMAMPUAN HOLISTIK GURU TERHADAP TEACHERS' PERFORMANCE DI SEKOLAH RAFFLES PONDOK INDAH TAHUN AKADEMIK 2018-2019
}

\author{
Natalia Simanjuntak \\ nafthalea@gmail.com \\ Manahan Tampubolon \\ manahan_tb@yahoo.com \\ Mesta Limbong \\ mesta.limbong@uki.ac.id
}

\begin{abstract}
ABSTRAK
Penelitian ini bertujuan untuk mengetahui pengaruh antara teachers' craft dan kemampuan holistik guru terhadap teachers' performance, dengan variabel bebasnya yaitu: Teachers' Craft $\left(\mathrm{X}_{1}\right)$, Kemampuan Holistik Guru $\left(\mathrm{X}_{2}\right)$, dan variabel terikatnya Teachers' Performance (Y). Penelitian ini dilakukan di Sekolah Raffles Pondok Indah I dan II selama bulan Maret-Juni 2019. Populasi dan sampel penelitian ini adalah semua guru Sekolah Raffles yang berjumlah 75 guru dengan teknik sampling jenuh. Instrumen penelitian adalah kuisioner yang memenuhi persyaratan validitas dan realibilitas dengan menggunakan model likert 1-4 Analisis data menggunakan uji korelasi sederhana, korelasi ganda, dan regresi ganda pada taraf signifikansi alpha 0,05 dengan menggunakan SPSS versi 24. Berdasarkan analisis data, diperoleh koefisien korelasi antara $\mathrm{X}_{1}$ dan $\mathrm{Y}$ sebesar 0,298 dan signifikan pada taraf 0,05 , sedangkan koefisien korelasi antara $X_{1}$ dan $\mathrm{X}_{2}$ dengan $\mathrm{Y}$ sebesar 0,130 dan signifikan pada taraf 0,05 . Kemudian analisis regresi diperoleh persamaan regresi antara $X_{1}$ dengan $Y$ yaitu $Y=61,184$ $+0,247 \mathrm{X}_{1}$. Persamaan regresi antara $\mathrm{X}_{2}$ dengan $\mathrm{Y}$ yaitu $\mathrm{Y}=\mathrm{Y}=3,319+0,021 \mathrm{X}_{2}$ dan persamaan regresi ganda antara $X_{1}$ dan $X_{2}$ dengan $Y=36,640+0,134 X_{1}+$ $0,051 \mathrm{X}_{2}$. Hasil penelitian ini menyimpulkan bahwa 1) terdapat pengaruh yang positif dan kurang signifikan antara teachers 'craft dan teachers' performance; 2) terdapat pengaruh yang positif dan kurang signifikan antara kemampuan holistik guru dan teachers' performance; 3) terdapat pengaruh yang positif dan sedikit signifikan antara teachers'craft dan kemampuan holistik guru secara bersamasama dengan teachers' performance.
\end{abstract}

Kata Kunci: teachers' craft, kemampuan holistik guru, teachers' performance 


\section{A. PENDAHULUAN}

Kreativitas dalam ilmu pengetahuan merupakan bagian dari pendidikan yang dapat diperbaharui sesuai dengan kemajuan dan tuntutan zaman dalam masyarakat.Dalam hal peningkatan intelektual diperlukan sebuah kreatifitas. Stephen P. Robbins dan Mary Coulter (2016: 228) mengatakan bahwa: Creativity refers to the ability to combine ideas in a unique way or to make unsual associations between ideas. A creative organization develops unique ways of working or novel solutions to problems. Menurut Wollfolk, kemampuan memecahkan masalah dengan cara baru merupakan cara pikir individu yang berpikiran positif, menarik, dapat diterima banyak kalangan serta mampu menciptakan hal baru yang berbeda dengan gagasan sebelumnya karena memiliki daya cipta. Perubahan teknologi dan Pendidikan semakin maju pesat merupakan hasil dari sebuah proses kreasi daya cipta orang-orang dari waktu ke waktu, baik dari era revolusi industri 1.0 pada akhir abad ke-18 dengan dikembangkannya mesin uap oleh James Watt lalu pekerjaan manusia mulai digantikan oleh mesin-mesin uap, era revolusi industri 2.0 ditandai dengan pengembangan energi dan peralatan listrik oleh ilmuan dan menerapkannya dalam industri tahap dua oleh Thomas Alpha dan Edison, kemudian pada tahun 1970-an revolusi industri 3.0 dimulai ketika kemajuan dalam otomatisasi bertenaga komputer memungkinkan kita memprogram mesin dan jaringan, lalu industri 4.0 yang disebut juga sebagai revolusi digital.Pada zaman globalisasi ini bahkan dunia sedang memasuki fase revolusi atau gelombang revolusi industri 5.0 bahkan 6.0 berbasis sistem fisik-siber telah datang begitu cepat dan serentak di hampir setiap negara di dunia, revolusi industri 5.0 dilabel sebagai revolusi industri ke-4 tiga dimensi yakni digital, fisik, dan biologi, hal ini merupakan isi sambutan Presiden RI Joko Widodo pada Serahsehan Nasional DPD RI. Keberadaan revolusi ini telah memunculkan berbagai pekerjaan baru yang pada lima atau sepuluh tahun lalu sama sekali tidak ada, namun dalam lima atau sepuluh tahun ke depan, diprediksi muncul pekerjaan baru yang saat ini belum eksis.

Misalnya sekarang sudah mulai ada profesi yang menjanjikan sepeti youtuber, pembuat game, penjualan jasa dan barang melalui e-commerce, bahkan profesi sekarang bisa digantikan oleh robot. Some students suggest that $65 \%$ of children entering primary school today will have jobs that do not yet exist and for which their education will fail to prepare them, exacerbating skills gaps and unemployment in the future workforce (World Economic Forum 2017). Berbagai kemampuan atau keterampilan yang diperlukan dalam perubahan yang terjadi di zaman ini mengharuskanpara pelaku pendidikan untuk mengubah baik kebijakan manajemen, performance guru dan pembelajarannya yang kreatif mencakup berbagai kemampuan holistik guru agar kebutuhan para siswa dapat terpenuhi secara utuh dan menyeluruh serta dapat menyiapkan mereka ke dunia kerja sesuai dengan tuntutan zaman ini.

Dalam dunia Pendidikan, kinerja guru atau performance guru dapat diukur oleh beberapa faktor di antaranya: kreativitas guru untuk menyampaikan materi pelajaran dan kemampuan holistik guru untuk mengintegrasikan materi dalam berbagai aspek kesatuan yang utuh dalam satu mata pelajaran. 
Pertama, kreatifitas guru yaitu untuk menanamkan guru-guru yang masih baru atau berpengalaman sekalipun dalam sebuah kreatifitas untuk melibatkan siswa secara bermakna, menginspirasi semangat untuk belajar dalam disiplin diri untuk tumbuh; memungkinkan siswa bebas untuk berinovasi dengan memelihara rasa ingin tahu mereka; menanamkan penghormatan yang takut akan Tuhan, untuk menjadi panutan yang baik bagi kaum muda lainnya dan melayani komunitas mereka. Dengan maksud inilah semua guru yang terlibat dalam program ini mengambil langkah-langkah menuju penguasaan profesi dan membuat perbedaan penting dalam kehidupan siswa.

Kedua, penguasaan Pendidikan secara holistik agar dapat mengintegrasikan bidang studi yang ada dengan utuh. Dengan adanya Pendidikan holistik setiap orang dapat menemukan identitas, makna, dan tujuan dalam hidup melalui hubungan dengan masyarakat, alam dan untuk nilai-nilai kemanusiaan seperti kasih sayang dan perdamaian. Ini adalah definisi yang diberikan oleh Ron Miller, pendiri jurnal pendidikan holistik (sekarang berjudul: Education for Meaning and Social Justice). Istilah Pendidikan holistik ini sering digunakan pada model pendidikan yang lebih demokratis dan humanistik Pendidikan. Rbin Ann Martin (2003:19) lebih lanjut menyatakan bahwa: "Pada tingkat yang paling umum, apa yang membedakan pendidikan holistik dari bentukbentuk lain dari Pendidikan adalah tujuannya, yaitu perhatian untuk belajar dari pengalaman".

Dengan Pendidikan, manusia bukan hanya harus dilatih dan dikembangkan cara berpikirnya sehingga diperoleh kecerdasan intelektualnya saja, melainkan dilatih dan dicerdaskan emosional dan spiritualnya.

\section{B. KAJIAN TEORI}

\section{Pengertian Teachers' Performance}

Kinerja merupakan bagian dari sekolah atau organisasi pendidikan yang bekerja di bidang jasa untuk menghasilkan produk manusia, oleh karena itu sekolah mempunyai sistem kerja yang terdiri dari sistem input (para murid, para staff pendidikan seperti: guru, kepala sekolah, staff non kependidikan seperti admin, bagian keuangan, bagian dan bagian manajemen, fasilitas, program sekolah) kemudian diproses dan menghasilkan output nilai yang bagus, serta kemajuan dari input itu sendiri yang kemudian menjadi outcome yaitu lulusan yang berkualitas dan sekolah menjadi unggul dan tempat yang difavoritkan. Namun dari input yang ada, kinerja guru yang didalamnya adalah yang paling menentukan hasil produk manusia di sekolah meskipun sekarang ini menggunakan student center learning dimana siswa lah yang menjadi pusat pembelajaran dan guru hanya sebagai fasilitator. Menurut Supradi (2016: 45) Kinerja merupakan suatu kegiatan yang dilakukan untuk melaksanakan, menyelesaikan tugas dan tanggung jawab sesuai dengan harapan dan tujuan yang telah ditetapkan. Dilihat dari arti kata kinerja berasal dari kata performance. Kata "performance" memberikan tiga arti, yaitu (1) "prestasi" seperti dalam konteks atau kalimat "high performance car", atau mobil yang sangat cepat (2) "pertunjukan" seperti dalam konteks atau kalimat "folk dance performance" atau pertunjukan tari-tarian rakyat (3) 
"pelaksanaan tugas" seperti dalam konteks atau kalimat "in performing his/her duties" (Ruky, 2002:14). Hal ini berarti kinerja adalah prestasi yang menunjukan suatu kegiatan atau tugas pelaksanaan yang dibebankan. Performance is defined as the record of outcome produced on a specified job function or activity during a specified time period, Bernardin dan Russel (1993: 378).

Pengertian kinerja tersebut di atas senada dengan pendapat Murray (2002:3) dalam Suharsaputra (2010:145) yang mendifinisikan kinerja adalah: "Basiclly, it (perfomance) means an outcome - a result, it is the end point of people, resources and certain environment being brought together, with intention of pruducing certain things, wheather tangible product of less tangible service. To the extent that this interaction results in an otcome of the desired level and quality, at egreed cost levels, performance will be judged as satisfactory, good, or excellent. To the extent that the outcome is disappointing, for whatever reason, performance will be judged as poor or dificient". Berdasarkan pendapatpendapat di atas dapat disimpulkan bahwa kinerja adalah catatan hasil kemampuan kerja yang telah dicapai oleh seseorang dalam suatu organisasi untuk mencapai tujuan berdasarkan atas standarisasi atau ukuran dan waktu yang disesuaikan dengan jenis pekerjaannya dan sesuai dengan norma dan etika yang telah ditetapkan serta mampu mengimplementasikan performa yang baik dari waktu ke waktu karena perkembangan ilmu pengetahuan semakin hari semakin maju. hasil riset, teacher quality is the most important determinant of the school quality yang tergabung dalam National Center for Educational Statistic di Amerika Serikat (NCES) dilaporkan bahwa standar kualitas yang harus dipenuhi oleh guru adalah: 1) the academic skils of teacher, 2) teacher assignment, 3) teacher experience, dan 4) professional development, Rivkin, Hamushek and Kain, 2005: 5).

Perkembangan mutu tiap tahunnya bukan hanya murid yang dinilai dan mendapat rapor, sebaiknya penilaian kinerja di sekolah juga harus dimiliki dan diterima oleh guru melalui tiga rapor sebagai penilaian, disusun dalam gambar sebagai berikut:

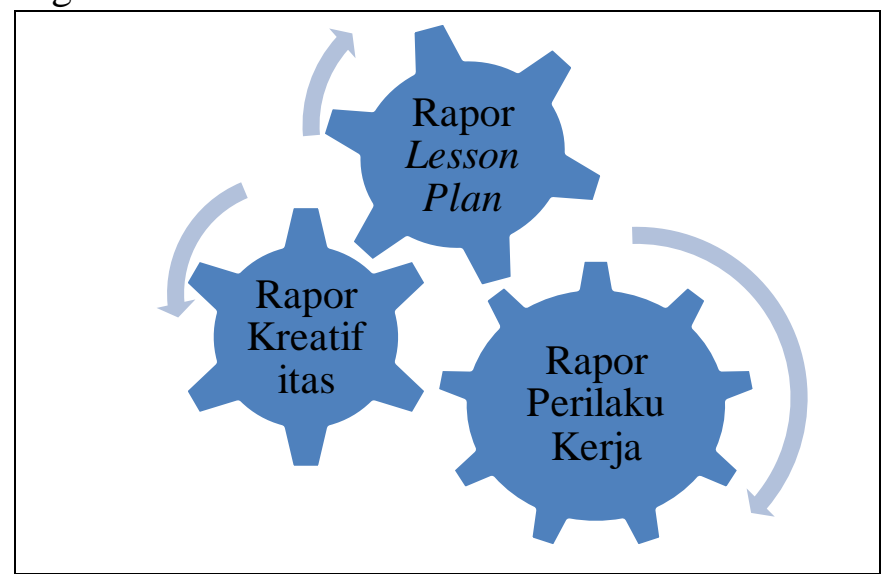

Penjelasan rapor guru sebagai penilaian kinerja guru secara spesifik memang harus ditulis dalam buku tersendiri. Secara ringkas, dapat dilihat dalam gambar bahwa rapor Pertama, perilaku kerja adalah rapor dengan 
area terluas, dengan kata lain itu mencerminkan bobot tertinggi sebab perilaku kerja lebih fokus mengukur komitmen kerja seorang guru. Ketika komitmen seorang guru yang baik akan berupaya kreatif dalam mengajar dan bekerja. Kreatifitas guru tidak akan terpantik jika guru tersebut memiliki komitmen yang rendah.Ada banyak sekali faktor lain yang mempengaruhi kinerja seorang guru diantaranya adalah kinerja yang diatur dalam Undang-Undang Nomor 14 Tahun 2005 tentang Guru dan Dosen pasal 10 ayat 1 menjelaskan bahwa kompetensi guru meliputi kompetensi pedagogik, kompetensi kepribadian, kompetensi sosial, dan kompetensi profesional yang diperoleh melalui pendidikan profesi

Dari keseluruhan referensi pakar tersebut, kinerja adalah suatu tindakan guru yang mengalamai perubahan dari waktu ke waktu serta mengalami tranformasi baik dalam disiplin guru seperti kehadiran, ethos kerja, efisiensi, dan efektifitas pembelajaran (kapasitas transformasi ilmu ke siswa), keteladanan guru dalam berbicara, bersikap, dan berprilaku, serta dalam memotivasikan belajar siswa. Inilah bagian dari penerapan kompetensi yang harus dipunyai guru dalam mewujudkan kinerja atau performance guru agar mendapatkan prestasi yang terbaik dan menjadi guru teladan bagi siswa, sesama kolega, staff non kependidikan, serta para pemimpin yang bekerja dalam sekolah tersebut. Dengan demikian, tercapainya pendidikan Indonesia yang maju dan merata sehingga dapat memberdayakan masyarakat Indonesia yang humanis di era bonus demografi seperti ini dengan menerapkan nilai-nilai kemanusiaan dan pendidikan.

\section{Kemampuan Holistik Guru}

Istilah holistik dalam bahasa Inggris adalah "whole" yang berarti keseluruhan. Selain itu, istilah holistik juga diambil dari kata heal (penyembuhan) dan health (kesehatan). Secara etimologis memiliki akar kata yang sama dengan istilah whole (keseluruhan). Dari sudut pandang filosofis pendidikan holistik merupakan suatu filsafat pendidikan yang berangkat dari pemikiran bahwa pada dasarnya seorang individu dapat menemukan identitas, makna dan tujuan hidup melalui hubungannya dengan masyarakat, lingkungan, dan nilai-nilai kemanusiaan seperti kasih sayang dan perdamaian.

Kemampuan holistik guru di sekolah juga merupakan salah satu indikator kesuksesan dalam profesinya, karena selain ilmu pengetahuan yang diajar atau disiplin ilmu yang diemban dan skill dalam manajemen sekolah, guru juga harus mengenal psikologi dan karakter peserta didik karena itu merupakan sikap dan karakter peserta didik selama berinteraksi dengan guru dimana menentukan proses belajar mengajar di sekolah. Dalam buku klasik Murray (1951: 276) “...Hal yang paling penting diketahui tentang individu ialah keterarahan, kegiatan-kegiatannya, baik mental, verbal, atau fisik" ini sama halnya dengan ungkapan-ungkapan taksonomi bahwa klasifikasi yang dilakukannya dengan tekun dan mendalam tentang unsurunsur tingkah laku manusia dipandang dari segi faktor-faktor penentu atau motif-motif yang melatarbelakanginya. 
Menurut Manahan Tampubolon (2012: 29) Individu seutuhnya (the whole person) memiliki kebutuhan fisiologis yang sama, tetapi tidak akan sama dalam memenuhi kebutuhan psikologis, disebabkan oleh latar belakang yang berbeda-beda (kognitif, afektif, serta psikomotorik). Berlandaskan ilmu perilaku, setiap individu memiliki keragaman dalam skala sikap dan perilaku (individual behavior), sehingga terdapat beberapa variabel yang menggambarkan perbedaan itu, antara lain kemampuan dan kepribadian.

Menurut Ratih Zimer (2011: 16) Kemampuan Holistik adalah kecerdasan intelektual, emosional dan spiritual menjadi "karakter" yang berarti ciri atau tanda khusus dan setiap individu yang menunjukkan adanya kekuatan atau kelemahan pada individu tersebut. Secara harfiah Furkon mengemukakan bahwa karakter berarti kualitas mental atau moral, kekuatan moral, nama atau reputasi.

Melalui Pendidikan karakter ini, anak akan terbentuk keseimbangan antara kecerdasan akademik (intelligent quotient), kecerdasan emosional (emotional quotient), dan kecerdasan spiritual (spiritual quotient), sehingga terbangun manusia Indonesia yang paripurna (beriman kepada Tuhan, bertanggung jawab, jujur, percaya diri, dan dapat meningkatkan etos kerja yang tinggi di masa yang akan datang.

Ketiga bangunan karakter itu, menurut Agustian (2002: 57) dapat dibuat ilustrasinya:

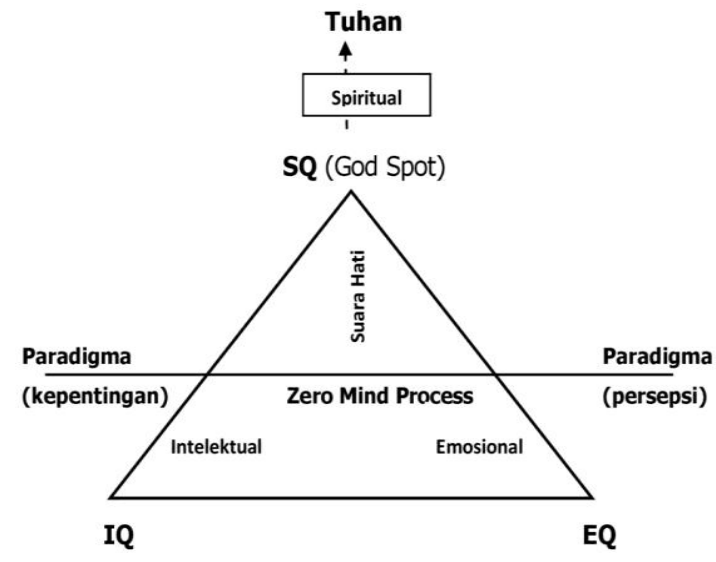

Gambar : (Hubungan antara IQ, EQ, SQ dan Tuhan)

Pendidikan Karakter di sekolah sangat dipengaruhi oleh perilaku guru, karena guru berhadapan langsung dengan peserta didiknya. Perilaku guru yang negatif dapat membunuh karakter anak (pemarah/ galak, kurang peduli, membuat anak merasa rendah diri, mempermalukan anak di depan kelas, dan lain-lain). Adapun perilaku guru yang postif, misalnya sering memberikan pujian, kasih sayang, adil, bijaksana, ramah dan santun. Strategi pembelajaran Pendidikan holistik menurut Jejen Musfah (2012: 182) dapat dilihat dalam empat bentuk integrasi, yaitu:

1. Integrasi ke dalam mata pelajaran

2. Integrasi melalui pembelajaran tematis

3. Terintegrasi melalui pembiasaan, dan 
4. Terintegrasi melalui kegiatan ekstrakurikuler

Dalam Pendidikan Holistik, peran dan otoritas guru untuk memimpin dan mengontrol kegiatan pembelajaran hanya sedikit dan guru lebih banyak berperan sebagai sahabat, mentor, dan fasilitator. Sekolah hendaknya menjadi tempat peserta didik dan guru bekerja guna mencapai tujuan yang saling menguntungkan. Komunikasi yang terbuka dan jujur sangta penting, perbedaan individu dihargai dan kerjasama lebih utama dari pada kompetisi. Gagasan Pendidikan Holistik telah mendorong terbentuknya model-model Pendidikan alternatif mungkin dalam penyelenggaraanya sangat jauh berbeda dengan Pendidikan pada umumnya, salah satunya adalah homeschooling, yang saat ini sedang berkembang termasuk di Indonesia. Berikut ini ada dimensi yang mempengaruhi kemampuan holistik guru, aspek yang pengembangan tersebut diantaranya adalah:

1. Pengembangan Aspek Spiritual

2. Pengembangan Aspek Estetik

3. Pengembangan Aspek Fisik

4. Pengembangan Aspek Intelektual

5. Pengembangan Aspek Emosional (Psikologi)

6. Pengembangan Aspek Sosial

Berdasarkan para pakar yang menjelaskan secara keseluruhan dari referensi kemampuan holistik di atas dapat disimpulkan bahwa penerapan kemampuan holistik dapat menumbuhkan karakter guru dan karakter yang muncul tertinggi adalah kedisiplinan dan tanggungjawab dalam menyelenggarakan Pendidikan agar mempersiapkan karakter secara emosional, intelektual dan spiritual dengan seimbang, lebih baik lagi serta Pendidikan holistik yang bertujuan untuk membantu mengembangkan berbagai potensi individu siswa dalam suasana pembelajaran yang lebih menyenangkan, demokratis dan humanis melalui pengalaman dalam berinteraksi dengan lingkungannya.

\section{Kreativitas Guru (Teachers' Craft)}

Berpikir kreatif merupakan sesuatu yang dikerjakan di luar dari standard dan menghasilkan sebuah karya atau kreatifitas dari skill yang dimiliki, Menurut James J. Gallagher dalam Yeni Rachmawati (2005:15) mengatakan bahwa "Creativity is a mental process by which an individual crates new ideas or products, or recombines existing ideas and product, in fashion that is novel to him or her" (kreativitas merupakan suatu proses mental yang dilakukan individu berupa gagasan ataupun produk baru, atau mengkombinasikan antara keduanya yang pada akhirnyakan melekat pada dirinya). Biasanya kita mengetahui sesuatu hanya jika kita memahaminya, kita memahami, hanya jika dapat menjelaskannya kepada diri kita dengan istilah kita sendiri. Menurut Chatib Munif (2019: 58) Pandangan orang kreatif kadang mendalam muncul pada orang yang mejanya bersih, file terorganisir dengan baik, serta mereka yang mendekati berpikir secara logis dan metodis. Namun, pemikir kreatifitas juga sering muncul pada orang yang rambutnya tidak rapi, tidak menemukan file yang dicarinya, punya pola berpikir tidak terencana, dan cenderung intuitif hanya mengikuti arus. Strategi ini menawarkan pendekatan yang lebih bebas, 
berasal dari penelitian tentang belajar dan kreatifitas Menurut Roger Schank, professor psikologi di Yale University ada sembilan prinsip dasar berpikir kreatif:

1. Mendapatkan semua data- sebelum memutuskan sebuah jawaban.

2. Mengklasifikasikan- dan menemukan klasifikasi baru.

3. Menggeneralisasikan untuk mendapatkan pandangan, ide, dan solusi baru.

4. Menjelaskan di luar standar berpikir orang.

5. Mencari apa yang tidak dipahami.

6. Menerapkan apa yang anda pelajari sebelumnya.

7. Menolak kebijaksanaan standar.

8. Membiarkan pikiran mengembara.

9. Memberikan izin kepada diri anda untuk gagal

Kreatif sendiri merupakan dasar seseorang untuk mengolah diri selalu pada posisi dinamis. Oleh karenanya sentuhan-sentuhan untuk menumbuhkan ide dan gagasan baru selalu dijadikan langkah awal dengan jalan memotivasi dan menstimulasi.Adapun beberapa teknik yang dilakukan untuk pelaksanaan teachers' craft dimana setiap guru bidang studi selain menanamkan materi secara holistik dengan berbagai macam aspek, sedangkan teachers' craft adalah bagaiamana menyampaikan ilmu yang ada kepada peserta didik dengan kemasan yang menarik dan kreatif agar siswa tidak cepat bosan dan lebih mengingat pembelajaran untuk lifelong learning diantaranya adalah:

1. Classroom routines atau kegiatan rutin kelas berdasarkan fitur utama dan hubungannya dengan peraturan kelas. Hal ini juga menjelaskan tentang keuntungan dari kegiatan rutin kelas adalah meliputi lingkungan pembelajaran seperti lesson pacing atau jeda pembelajaran, akuntabilitas sosial dan kesejahteraan siswa. Saphier, J., Haley_Speca, M., and Gower. R. (2008: 64).

2. Tujuan pembelajaran supaya efektif dalam mengajar dan pembelajaran yang lebih baik. Ada tahapan-tahapan dalam merencanakan sebuah pembelajaran menggunakan desain yang terdahulu agar membuat konten dan aktifitas sekarang lebih relevan dengan para siswa. Struktur untuk menulis tujuan pembelajaran lebih spesifik dan terukur dimana dapat dimengerti dan dapat dicapai .http://www.cusoeproffesionaleducation.org/

3. Menjelaskan karakteristik dari tiga bagian pembelajaran dan beberapa saran untuk membuat para siswa lebih efektif. Adapun beberapa cara menyusun kegiatan pembelajaran sehingga para siswa dapat mengikuti rangkaian urutan pembelajaran. Definisi Scaffolding atau papan kegiatan dan bagaiamana mengintegrasikannya dengan sebuah pembelajaran untuk perkembangan siswa yang lebih baik. Serta, strategi konsolidasi untuk menolong bagaimana guru merencanakan pembelajaran https://www.edutopia.org/blog/scaffolding-lessons-six-strategiesrebecca-alber. 
4. Teaching Transitions Techniques for promoting success between lessons. Eugene: Council for Exceptional children, (2017: 32-38). Strategies to improve Transitions and Time Management, hal ini menjelaskan bagaimana mengatur waktu di kelas sampai kepada waktu transisi di dalam kelas. https://wwwteachingchannel.org/videos/improve-transitions-timemanagement

5. Karakteristik dari perbedaan tipe masa transisi kelas dan pacing(waktu sibuk), saran bagaimana menyusun masa transisi di kelas dan pembelajaran di waktu sibuk dalam kelas. Cara bagaiamana berbagi harapan yang ingin dicapai supaya lebih transparan dalam menyusun masa transisi dan pacing (waktu sibuk). Metode mengembangkan kebiasaan diri untuk reflektif atau bercermin diri dan self- management agar siswa dapat menangani masa transisi di jam sibuk mereka.

6. Changing Minds Terdiri dari beberapa daftar perbedaan alasan guru menggunakan pertanyaan dengan penjelasan untuk memberikan dampak kepada para siswa, penjelasan dengan contoh bagaimana membedakan open-ended dan pertanyaan penutup. Contoh dari thinking question dari yang terendah sampai tertinggi dari sebuah metode untuk menciptakan pertanyaan tersebut di dalam scaffold learning (Pembelajaran dengan urutan di papan). Adapun teknik bagaimana mengimplementasikan pengajaran selama berlangsung sampai bertanya kepada pertanyaan yang lebih efektif.(http://changingminds.org/techniques/questioning/open_cl osed_questions.htm

7. Whys and Hows of Assessment. What is the difference between formative and summative assessment? Tujuan penilaian dan perbedaan antara penilaian formatif dan penilaian sumatif dengan cara mengidentifikasikan definisi dan intens. Menganalisis latihan guru dalam fitur administrasi dari penilaian formatif; kriteria khusus/ rubrik, monitoring, evaluasi diri dan feedback. Adapun cara memberikan feedback yang efektif dengan membuatnya tepat waktu, ditindaklanjuti, spesifik dan konstruktif (http://www.cmu.edu/teaching/assessment/basics/formative_sum mative.html).

Menurut referensi dan para pakar yang menjelaskan secara keseluruhan dari kreativitas guru di atas dapat disimpulkan bahwa seorang guru yang berkompeten, selain harus mampu mengintegrasikan satu mata pelajaran kedalam berbagai aspek kehidupan siswa yang holistik, guru dituntut bukan hanya pintar secara ilmu akademik dari lulusan luar negeri atau bergelar tinggi namun harus bisa membuat packaging yang menarik 
dalam mengajar bukan yang tradisional atau mengingat-ingat memori guru yang lampau tetapi guru harus menciptakan pembelajaran yang kreatif dengan melihat fenomena yang terjadi dan mengikuti perkembangan zaman agar para siswa tidak bosan dan semangat dalam belajar.

Model kerentanan bersama menjelaskan hubungan antara kreativitas dan psikopatologi. Model ini, didukung oleh temuan baru-baru ini dari ilmu saraf dan genetika molekuler, menunjukkan bahwa faktor-faktor penentu biologis yang memberikan risiko untuk psikopatologi berinteraksi dengan faktor kognitif pelindung untuk meningkatkan ide kreatif. Unsur-unsur kerentanan bersama termasuk disinhibisi kognitif (yang memungkinkan lebih banyak rangsangan ke dalam kesadaran), gaya perhatian yang didorong oleh arti-penting baru, dan hyperconnectivity saraf yang dapat meningkatkan hubungan antara rangsangan yang berbeda.

Kerentanan ini berinteraksi dengan faktor-faktor pelindung meta-kognitif yang unggul, seperti IQ tinggi, kapasitas memori kerja yang meningkat, dan peningkatan fleksibilitas kognitif, untuk memperbesar jangkauan dan kedalaman rangsangan yang tersedia dalam kesadaran untuk dimanipulasi dan dikombinasikan untuk membentuk ide-ide baru dan asli.

1. Sew Kim Low, Jin Kuan Kok, Mah Ngee Lee. (2013) yang berjudul A holistic approach to school.Temuan menunjukkan bahwa ada kurangnya kolaborasi antara berbagai pemangku kepentingan pendidikan dan sumber daya dari masyarakat tidak dimanfaatkan secara efektif. Sebagai hasil dari penelitian ini, model integratif komprehensif dapat membantu guru agar mengajarkan setiap siswa mempunyai kemampuan secara keseluruhan atau holistik dalam setiap mata pelajaran di sekolah.

\section{METODOLOGI PENELITIAN \\ Tujuan Penelitian}

Penelitian ini bertujuan untuk mencari pengaruh variabel bebas Teachers' Craft dan Kemampuan Holistik Guru terhadap variabel terikat yaitu Teachers'Performance. Penelitian ini merupakan penelitian kausal komparatif, karena penelitian ini bertujuan untuk mengetahui kemungkinan adanya hubungan sebab akibat dengan cara tertentu berdasarkan atas pengamatan terhadap akibat yang ada, kemudian mencari kembali faktor yang diduga menjadi penyebabnya, melalui pengumpulan data (Suharsimi Arikunto, 2010: 121).

\section{Tempat dan Waktu Penelitian}

Penelitian ini dilaksanakan di Sekolah Raffles Pondok Indah yang beralamatkan di Jalan Gedung Hijau I No. 1 Pondok Indah Jakarta Selatan. Penelitian dimulai dari bulan Maret- Juli 2019 dan Pengambilan data dilaksanakan pada awal bulan Juni 2019.

\section{Metode Penelitian}

Penelitian ini menggunakan metode penelitian pendekatan kuantitatif riset survey yakni penelitian yang menekankan analisisnya pada data statistik. Data berupa angka yang diperoleh dari angket atau kuesioner. Metode 
penelitian ini menggunakan pendekatan korelasional. Rancangan penelitian ini terdiri dari tiga variable, dan ketiga variable tersebut dihubungkan dalam model teoretik seperti gambar berikut:

Hubungan antara variabel independen dengan variabel dependen tersebut dapat dilihat melalui paradigma sebagai berikut:

Model Teoretik

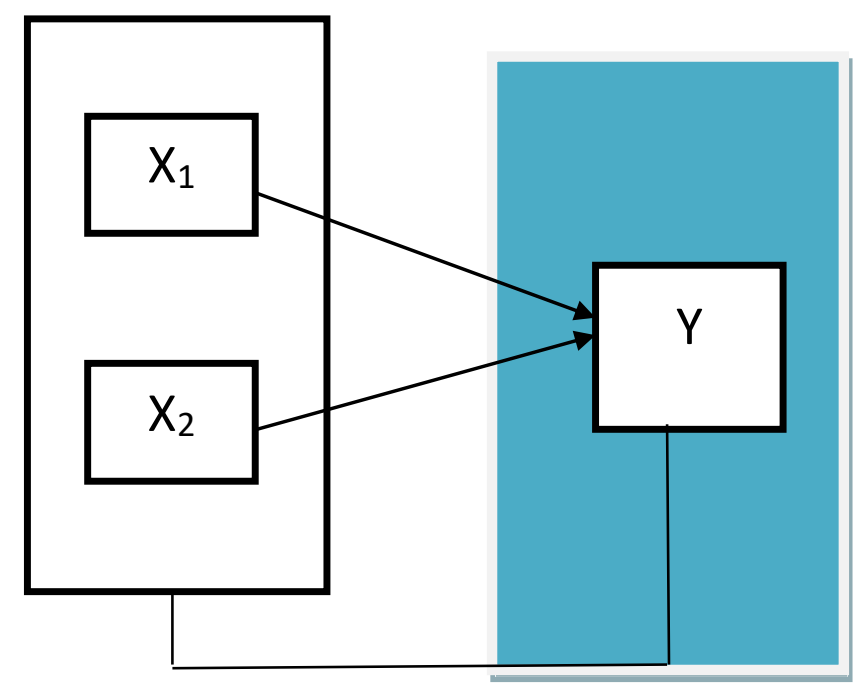

Keterangan :

$\mathrm{X}_{1}=$ Teachers' Craft

$\mathrm{X}_{2}=$ Kemampuan Holistik Guru

$\mathrm{Y}=$ Teachers' Performance

Penelitian menggunakan angket yang bersifat tertutup, yaitu angket yang memilih salah satu jawaban yang telah disediakan. Pengembangan instrumen penelitian ini didasarkan pada variabel-variabel yang akan diteliti. Dari variabel-variabel tersebut diberikan definisi operasionalnya, dan selanjutnya ditentukan indikator yang akan diukur. Dari indikator kemudian dijabarkan menjadi butir-butir pertanyaan atau pernyataan. Pengukuran angket menggunakan Skala Likert yang dimodifikasi menjadi empat alternatif jawaban untuk menentukan skor instrumen dan menghindari jawaban yang ragu-ragu dari responden serta keperluan analisis kuantitatif. Responden memberikan tanda centang $(\sqrt{ })$ pada kolom yang telah tersedia. Skor setiap alternatif jawaban yang diberikan oleh responden pada pernyataan positif $(+)$ dan pernyataan negatif (-) adalah sebagai berikut:

Tabel 2: Skor Alternatif Jawaban Butir Pernyataan Instrumen

Penelitian

\begin{tabular}{cc}
\hline Alternatif Jawaban & Bobot Skor \\
\hline Sangat Setuju & 4 \\
Setuju & 3 \\
\hline
\end{tabular}




\begin{tabular}{cc}
\hline Tidak Setuju & 2 \\
Sangat Tidak Setuju & 1 \\
\hline
\end{tabular}

\section{Uji Coba Instrumen}

Uji coba instrumen ini dilakukan pada 20 guru di Sekolah Raffles, Pondok Indah. Uji coba instrumen ini menggunakan Uji Validitas dan Uji Reliabilitas. Uji Validitas dilakukan berkenaan dengan ketepatan alat ukur terhadap konsep yang diukur sehingga benar-benar mengukur apa yang seharusnya diukur. Selanjutnya dihitung realibilitasnya terhadap skor butir-butir pernyataan yang telah dinyatakan valid. Uji reliablilitas dilakukan untuk mendapatkan tingkat ketepatan (keterandalan dan keajegan) instrument yang digunakan dengan menggunakan rumus realibilitas yakni Alpha Cronbach.

\section{Instrumen Final}

Berdasarkan hasil uji coba instrumen yang telah dilaksanakan kepada 20 guru di Sekolah Raffles, Pondok Indah dengan menggunakan aplikasi software SPSS Statistik 24. Dari uji hasil uji statistic dapat diperoleh hasil uji validitas instrumen penelitian sebagai berikut:

a. Uji Validitas Alat Ukur Teachers' Craft (X1) Berdasarkan indikatorindikator dari variabel Teachers' Craft yang dikembangkan menjadi 30 butir pernyataan variabel Teachers' Craft (X1), terdapat 16 butir pernyataan yang valid dan 14 butir pernyataan yang tidak valid atau gugur, yaitu nomor 3, 4, 7, 8, 12, 13, 19, 20, 21, 22, 24, 25, 28, dan 29.

b. Uji validitas alat ukur kemampuan holistik guru (X2). Berdasarkan indikator-indikator dari variabel kemampuan holisitik yang dikembangkan menjadi 30 butir pernyataan variabel kemampuan holistik guru (X2), terdapat 22 butir pernyataan yang valid dan 8 butir pernyataan yang tidak valid atau gugur, yaitu nomor 3, 5, 10, 11, 12, 23, 26, dan 27.

c. Uji Validitas Alat Ukur Performance Guru (Y) berdasarkan indikatorindikator dari variabel Performance Guru (Y), terdapat 30 butir pertanyaan yang valid dan 10 butir pertanyaan yang tidak valid atau gugur, yaitu nomor 1, 2, 4, 11, 13, 19, 21, 22, 34, dan 40 .

\section{Reliabilitas}

Instrumen dikatakan reliabel jika $r$ hitung lebih besar atau sama dengan $r$ tabel dan sebaliknya jika $r$ hitung lebih kecil dari $r$ tabel maka instrumen dikatakan tidak reliabel atau nilai $r$ hitung dikonsultasikan dengan tabel interperetasi $r$ dengan ketentuan dikatakan reliabel jika $r$ hitung $\geq 0,600$. Uji reliabilitas dalam penelitian ini dengan bantuan program aplikasi statistika.

A. Diketahui Cronbach's Alpha pada $X_{1}$ adalah sebesar 0,894Kriteria Nunanally (1960): Cronbach Alpha lebih besar dari $60 \%$, maka kuisioner/indikator variable disebut Reliable.0, $894=89,4 \%$ lebih besar dari $60 \%=$ Reliable dengan interpretasi tinggi.

B. Diketahui Cronbach's Alpha pada $\mathrm{X}_{2}$ adalah sebesar 0.940Cronbach Alpha lebih besar dari $60 \%$, maka kuisioner/ indikator variable disebut 
Reliable. $0,940=94 \%$ lebih besar dari $60 \%=$ Reliable dengan interpretasi sangat tinggi

C. Diketahui Cronbach's Alpha pada y adalah sebesar 0.967Cronbach Alpha lebih besar dari $60 \%$, maka kuisioner/ indikator variable disebut Reliable. 0, $967=96,7 \%$ lebih besar dari $60 \%=$ Reliable dengan interpretasi sangat tinggi.

\section{HASIL PENELITIAN}

Dari hasil analisis deskripsi tiap variabel, dapat diperoleh hasi perhitungan rata-rata butir skor dari seluruh sampel untuk teachers' craft, kemampuan holistik guru, dan teachers' performance masing-masing sebesar 3,3; 3,3; dan 3,9. Dari persentase nilai yang diperoleh dengan nilai maksimal yang bisa diperoleh dari variabel tersebut adalah masing-masing sebesar $31 \%, 31 \%$, dan $29 \%$ dari skor maksimal yang bisa diperoleh. Hal ini berarti bahwa tingkat penggunaan teachers' craft, kemampuan holistik guru dan teachers' performance di Sekolah Raffles secara keseluruhan cukup tinggi.

1. Terdapat hubungan yang positif dan signifikan antara variabel teachers' craft, dengan teachers' performance. Hal ini ditunjukan dengan nilai $\mathrm{t}$ hitung sebesar 41,647kemudian diperoleh koefisien korelasi $\left(\mathrm{r}_{\mathrm{y} 1}\right)$ sebesar 0,298 yang berarti korelasi bernilai positif dan cukup kuat, koefisien determinasi $\left(\mathrm{r}^{2} \mathrm{yl}\right)$ sebesar $17 \% \%$ dan persamaan regresi $\mathrm{Y}=61,184+$ $0,247 \mathrm{X}_{1}$

2. Terdapat hubungan yang positif dan signifikan antara kemampuan holistik guru dengan teachers' performance. Hal ini ditunjukan dengan nilai $\mathrm{t}$ hitung sebesar 0,159 kemudian diperoleh koefisien korelasi $\left(\mathrm{r}_{\mathrm{yl}}\right)$ sebesar 0,853 yang berarti korelasi bernilai positif dan cukup kuat, koefisien determinasi $\left(\mathrm{r}^{2} \mathrm{y}\right)$ sebesar $16 \%$ dan persamaan regresi $\mathrm{Y}=$ $3,319+0,021 X_{2}$

3. Terdapat hubungan yang kurang positif dan signifikan antara teachers' craft dan kemampuan holistik guru bersama-sama dengan teachers' performance. Hal ini ditunjukan dengan nilai $F_{\text {hitung sebesar } 0,619}$ Kemudian diperoleh koefisien korelasi ganda ( $\mathrm{r}_{\text {y12 }}$ ) sebesar 0,130. yang berarti korelasi bernilai kurang positif dan kuat sedangkan koefisien determinasi $\left(\mathrm{r}^{2} \mathrm{y}^{12}\right)$ sebesar $10 \%$ dan persamaan regresi $\mathrm{Y}=$ $36,640+0,134 \mathrm{X}_{1}+0,051 \mathrm{X}_{2} \mathrm{Y}=3,319+0,021 \mathrm{X}_{2}$ dan $\mathrm{Y}=36,640+$ $0,134 \mathrm{X}_{1}+0,051 \mathrm{X}_{2}$

\section{E. KESIMPULAN DAN SARAN \\ Kesimpulan}

Implikasi yang disajikan peneliti melalui hasil penelitian ini adalah sebagai berikut: Dari hasil perhitungan dapat diperoleh kesimpulan bahwa penggunaan teachers ' craft dan kemampuan holistik guru terhadap teachers' performance di Sekolah Raffles sangat tinggi. Performance yang baik tersebut didukung oleh kemampuan holistik dan kreatifitas guru yang memadai. Perasaan yang positif tersebut membuat para guru mengoptimalkan fasilitas dengan melakukan hal yang kreatif dan mengoptimalkan seluruh potensi mereka dalam hal kemampuan holistik yang mereka miliki. Kemudian tingginya kemampuan holistik guru juga dapat mereka salurkan 
kepada peserta didik dengan kreatif sehingga dapat memenuhi kebutuhan siswa baik afektif, psikomotorik dan kognitif dan dapat menjawab tuntutan zaman yang semakin bertumbuh dengan cepat. Hal ini merupakan awal yang baik bagi performance guru di Sekolah Raffles dalam mengelola bahan materi yang baik sehingga para siswa mengelurakan potensi dan kemampuanya secara holsitik dan bekerja bukan karena text book oriented tetapi lebih demokratis dan menyeluruh seluruh aspek yang didapat dalam sehari-hari.

1. Bukti empirik menunjukan bahwa teachers' performance sedikit dipengaruhi oleh brand atau produk teachers' training yang bernama teachers'craft, Hal ini menunjukan guru-guru sudah profesional sehingga hal teknis seperti ini tidak begitu berpengaruh, ada faktor terbesarlain yang mempengaruhi performace guru yang belum diteliti.

2. Bukti empirik menunjukan bahwa teachers' performance sedikit dipengaruhi oleh kemampuan holisitk guru, Hal ini menunjukan guruguru dianggap profesional sehingga kemampuan holistik pun sudah hal yang lumrah dan ini sedikit berpengaruh, ada faktor lain yang mempengaruhi performace guru yang belum diteliti.

3. Bukti empirik menunjukan bahwa teachers'craft bersama-sama dengan kemampuan holistik guru mempengaruhi teachers' performance, Hal ini menunjukan guru-guru profesional sehingga kemampuan holistik dan craft pun sudah hal yang lumrah sehingga faktor lain yang mempengaruhi performace guru yang belum diteliti harus lebih dikembangkan lebih lagi.

\section{Saran}

Setelah menyimpulkan dan membuat implikasi berdasarkan penelitian serta didukung oleh teori-teori yang ada, maka peneliti mencoba memberikan masukan dan saran sebagai berikut:

1. Bagi sekolah kiranya dapat memberikan pembelajaran yang demokratis baik kepada guru dan siswa dengan fasilitas yang ada namun tetap terkontrol agar tercipta kreasi yang berkembang dan membuat suatu daya cipta terbaru dan penemuan untuk menjawab tuntutan zaman yang semakin berubah di segala aspek sehingga guru dapat mengarahkan segala kemampuan yang ada dan nyaman dengan para guru lain sehingga tidak menimbulkan persaingan yang merugikan dan berakibat kepada para siswa.

2. Bagi guru, dapat terus mengembangkan potensi yang ada baik kreatifitas pembelajaran sampai kepada kemampuan holistik sehingga membuat para siswa dan orang tua merasa puas dengan pelayanan akademik dan manajemen sekolah serta membuat psikologi siswa menjadi lebih baik dan terarah.

3. Bagi peneliti, yang ingin mengetahui pengaruh antara teachers' craft dan kemampuan holistik guru terhadap teachers' performance lebih dalam, dapat menambah sampel atau meneliti sekolah serta kedepannya dapat mengetahui variabel atau faktor yang lain yang dapat mempengaruhi teachers' performance di masa yang akan datang melalui hasil penelitian selanjutnya sehingga sekolah dapat mendapatkan output yang baik agar 
menciptakan lulusan atau outcome yang berkualitas sampai kelas dunia seperti visi dan misi yang telah diungkap di halaman pendahulan sebelumnya.

\section{DAFTAR PUSTAKA}

Agustian, Ary Ginanjar. (2002). Rahasia Sukses Membangun Kecerdasan Emosional dan Spiritual; ESQ.Jakarta : Arga

Bernardin and Russel. (1993). Human Resource Management. New Jersey: International Editions Upper Saddle River. Prentice Hall.

Chatib Munif. (2019). Gurunya Manusia, strategi multiple intelligences menjadikan semua anak istimewa dan semua anak juara. Bandung. Kaifa.

Himpunan Peraturan Perundang-Undangan Republik Indonesia. (2015). UndangUndang Guru dan Dosen (UUD RI Nomor 14 Tahun 2005). Yogyakarta. Pustaka Mahardika.

Jejen Musfah Ed. (2012). Pendidikan Holistik. Jakarta: Kencana Prenada Media Group.

Lickona Thomas. (2012). (Bahasa Indonesia Version) Educating for Character. Jakarta. PT Bumi Aksara.

Marzuki. (1997) Kajian Sekolah Berprestasi di

Malaysia: Model Lima Faktor. Malaysia

Murray, Lindzey Gardner dan Hall, Calvin. (1993). Teori-Teori Holistik Murray, Goldstein, Angyall, Maslow, Rogers, Binswanger, Boss, dan Lewin (OrganismikFenomenologis). Yogyakarta. Kanisius.

Nurhayati. (2006) faktor-faktor yang mempengaruhi Profesionalisme dan Kinerja Guru di SMAN Kota Makasar Sulawesi Selatan.

Rbin Ann Martin. (2003). Behavior Modification :What It Is and How To Do It. Upper Saddle River : Prentice Hall, Inc.

Rivkin, Hamushek and Kain. (2005). Teachers, Schools, and Academic Achievement. Journal of Econometrica.

Robbin, Stephen P and Mary Coulter. (2016). Management, The United State of America: Pearson Education Limited

Ruky, Achmad S. (2002). Sistem Manajemen

Kerja, Cetakan Ketiga, PT Gramedia Pustaka Utama, Jakarta.

Sew Kim Low, Jin Kuan Kok, Mak Ngee Lee (2013) A holistic approach to school. Universiti Tunku Abdul Rahman, Malaysia.

Sitepu, Ied Veda. (2019). Kapita Selekta Magister Administrasi/ Manajemen Pendidikan, mengutip dari world economic. Jakarta. UKI Press.

Suharsimi Arikunto, (2010). 2010. Prosedur Penelitian Suatu pendekatan Praktek. Jakarta: Rineka Cipta.

Supradi. (2013). Kinerja Guru. Jakarta. Rajawali Pers.

Tampubolon, Manahan. (2015). Perilaku Keorganisasian (Organization Behavior). Bogor. Ghalia Indonesia.

\section{Sumber Online}

Alber, R. (2011), 6 Scaffolding Strategies to use with your students Edutopia. Available at https://www.edutopia.org/blog/scaffolding-lessons-six-strategiesrebecca-alber. [Accessed 9 Feb 2017] 
Pengaruh Teachers' Craft Dan Kemampuan Holistik Guru Terhadap Teachers' Performance Di Sekolah Raffles Pondok Indah Tahun Akademi 2018-2019

Changing Minds (2016) Open and closed questions. http://changingminds.org/techniques/questioning/open_closed_questions.htm[Acc essed 7 Aug. 2017]

http://jurnal.untan.ac.id/index.php/jpdpb/article/view/3468/pdfhttps://www.edutop ia.org/blog/scaffoldin-lessons-six-strategies-rebecca-alber (Accessed 9 Feb 2017) Petty, G (2017) improve your teachingand that of your team http://geoffpetty.com (Accessed 15 Sept 2017)

The A, B,C, D Method of Writing Measureable Objectives (2014) [pdf] Raleigh: Campbell University,PP.1-2Ahttp://www.cusoeproffesionaleducation.org/ uploads/2/9/5/8/ 29585257/ writing_objectives_abcd 2014.pdf [Accessed 27 Jul 2017]

Whys and Hows of Assessment. (2015). What is the difference between formative and summative assessment?

http://www.cmu.edu/teaching/assessment/basics/formative_summative.html [Accessed 8 Aug 2017] 